\title{
鉄道における雨量計の配置間隔に関する考察 A STUDY ON THE INSTALLATION INTERVAL OF RAIN GAUGE FOR RAILROAD
}

\author{
鈴木博人 ${ }^{1} \cdot$ 中北英一 ${ }^{2} \cdot$ 高橋日出男 ${ }^{3}$ \\ Hiroto SUZUKI, Eiichi NAKAKITA, Hideo TAKAHASHI \\ ${ }^{1}$ 正会員 理修 東日本旅客鉄道株式会社千葉支社設備部( ( $260-0031$ 千葉県千葉市中央区新千葉 1-3-24) \\ ${ }^{2}$ 正会員 工博 京都大学防災研究所教授( ( $606-0011$ 京都府宇治市五ヶ庄) \\ $3^{3}$ 非会員 理博 首都大学東京大学院都市環境科学研究科教授（广192-0397 東京都八王子市南大沢 1-1)
}

\begin{abstract}
Train operation is stopped to ensure safety when the precipitation observed by a rain gauge exceeds a predetermined value. This paper proposes a method to determine the installation interval of rain gauges for railroads suitable for hourly precipitation which is often used as the index of rainfall intensity. The installation interval of rain gauges is evaluated from viewpoint of both safety and reliability of train operation, based on the spatial distribution of precipitation observed by rain gauges. The results is that when the installation interval of rain gauges is reduced from $10 \mathrm{~km}$, the current standard in JR East's, to $5 \mathrm{~km}$, the rate of increase in safety exceeds the rate of decrease in reliability. The conclusion is, therefore, the installation interval of rain gauges should be set at $5 \mathrm{~km}$.
\end{abstract}

Key Words : rain gauge, installation interval, railroad, safety, reliability, spatial distribution, hourly precipitation

\section{1.はじめに}

鉄道では，降雨に起因した土砂災害などから列車運行 の安全を確保するために，災害を発生させる恐れのある 大雨が生起した場合に，運転中止や速度規制といった列 車運転規制を行っている ${ }^{1)}$. 列車運転規制は，地上雨量 計の観測值のみに基づく単純な方法であるが，降雨時の 列車運行の安全に大きな貢献を果たしてきた。しかし, 降雨に起因した全ての降雨災害が運転中止中に発生する わけではないことから，列車運転規制方法は長年に亘つ て改良が加えられてきた. その改良の多くは雨量指標に ついてであり, 雨量計の設置間隔については十分な検討 がなされてきたとはいえない。これは，鉄道の多くが雨 量計の設置間隔を $10 \mathrm{~km}$ を標準としており ${ }^{1), 2)}$, このよう な狭い間隔で設置された雨量計の設置間隔を雨量計で観 測された降水量データを用いて定量的に評価するのが困 難であったためである.しかし，近年では複数の機関に おいて雨量計の観測網が整備され，降水量データが蓄積 されてきた. そこで, 本研究では複数の機関の雨量計で 観測された降水量データを利用して，2 地点間の距離が $10 \mathrm{~km}$ 以下，つまりメソ $\gamma$ スケールにおける降水量の空 間分布を定量的に把握した上で，鉄道における雨量計の 設置間隔を評価する方法について考察した.

雨量計の配置に関する研究として, 村上ほか ${ }^{3}$ は神奈 川県内における $5 \mathrm{~km}$ メッシュのレーダーアメダス解析
雨量を用いて, 2 地点の 1 時間降水量の差異が 10\%以内 の範囲は $1 \mathrm{~km}$ 程度, $20 \%$ の範囲は $2 \mathrm{~km}$ 程度としている。 井良沢・田口 ${ }^{4}$ は, 雨量計の観測值が代表し得る範囲を 2 地点における 1 時間降水量の相関係数が 0.9 以上の範 囲とし，新潟県山間部における雨量計の観測值から，そ の範囲を $3 \mathrm{~km}$ 前後としている. また，建設省土木研究所 ${ }^{5}$ は，雨量計の設置箇所と災害発生地点の距離の検討か ら, 災害発生箇所の降水量を把握寸るには概称 $5 \mathrm{~km}$ 以内 での観則が必要としている.

最近では, メソ $\gamma$ スケールにおける降水量の空間分布 に関して, 鈴木ほかの などによって鉄道や気象庁などの 複数の機関が設置した多数の雨量計による降水量デー タを用いた統計的な解析が行われた．鈴木ほかのでは一 定以上の降雨が生起したときの 2 地点の降水量比，鈴 木・高橋》)では一定以上の降雨が同時に生起した割合 (同 時生起率 $\left.{ }^{8}\right)$ について，2 地点間の距離との関係を解析 した，そこで，本研究ではこれらの成果を利用して，降 雨強度の雨量指標として用いられることの多い 1 時間降 水量を対象に, 雨量計の設置間隔を列車運行の安全性と 安定性の両面から評価寸る方法について考察した.

\section{2 降水量データと解析フロー}

\section{（1）降水量データ}

対象と寸る地域は，降水量に与える地形の影響が小さ いと考えられる関東平野の標高 $150 \mathrm{~m}$ 以下の地域(図-1) 


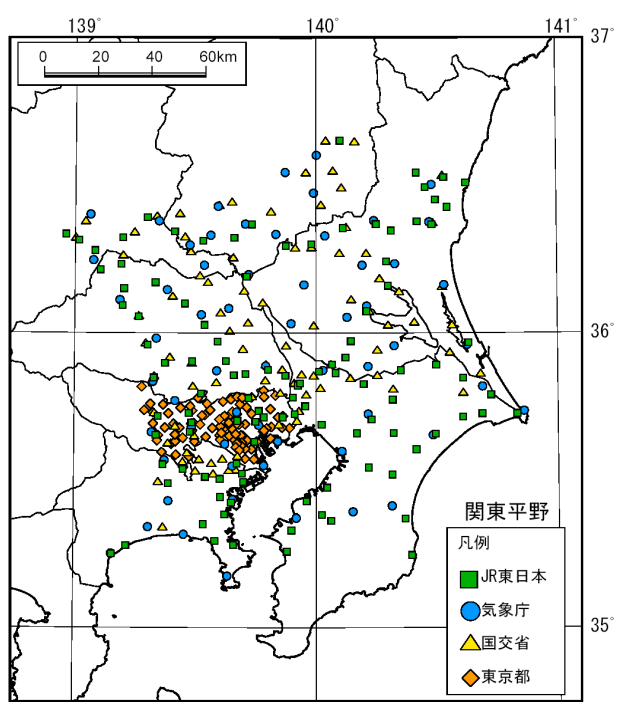

図-1 解析に用いた雨量計の位置.

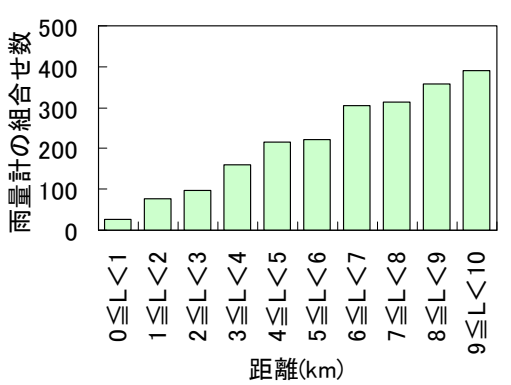

図-2 1km ごとの雨量計の組合せ数.

とし, 東日本旅客鉄道株式会社 (以下, JR 東日本とする) の防災情報システム ${ }^{9)}$, 気象庁の地域気象観測システム

（アメダス），国土交通省の水文水質データベース ${ }^{10)}$, 東京都の東京都水防琰総合情報システム ${ }^{11)}$ の雨量計で 観測された正時の 1 時間降水量を用いて分析を行った. 雨量計の地点数は図-1 に示す 347 地点で, JR 東日本が 110 箇所，気象庁が 60 箇所，国土交通省が 87 箇所，東 京都が 90 箇所である.これらの雨量計の組合せ数は図-2 に示寸とおりで， 2 地点間の距離が $10 \mathrm{~km}$ 以下の組合せ が 2,175 組存在する. 対象期間は, 1991 年から 2007 年の 17 年間の暖候期（5 月〜 10 月）で，この期間に延べ 10 年以上の降水量データがある地点を対象にした.

\section{(2) 解析フロー}

降雨時の列車運転規制を行う際の基本は，降雨により 被る危険を十分に回避（安全の確保）した上で，列車の 運行を可能な限り確保（安定性の確保）することである 12)。そこで, 本研究では雨量計の設置間隔を列車運行の 安全性と安定性の両面から評価することとし, 評価にあ たって以下のとおり仮定した.

(a) 一般的に大雨とされる 1 時間降水量が $30 \mathrm{~mm}$ 以上の 場合を大雨とみなし，列車運転規制の運転中止基準值を 1 時間降水量が $30 \mathrm{~mm}$ と仮定する. なお，実際の運転中 止基準値は，雨量計の受け持ち区間ごとに異なっている. (b) JR 東日本における運転中止基準值と速度規制基準值 の比は平均すると 1.2 程度であることから，2 地点の 1

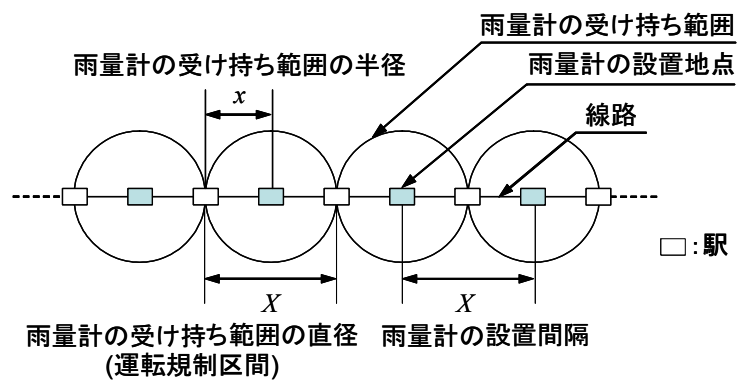

図-3 雨量計の設置間隔と雨量計の受け持ち範囲の関係 表-1 雨量計の設置間隔の評価基準

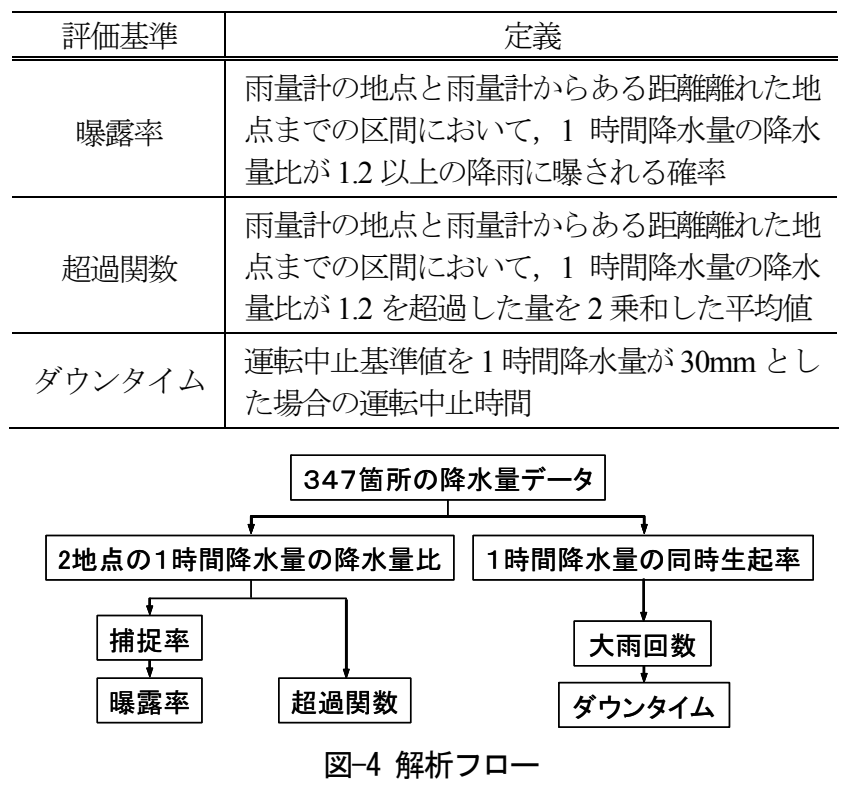

時間降水量の降水量比が 1.2 以下であれば大雨を捕捉で きたと考えることにする．これは，運転規制区間（ $X$ : 雨量計の受け持ち範囲の直径, 図-3）内のある地点の降 水量が雨量計の地点の降水量の 1.2 倍以下であ孔ば， あ る地点で運転中止基準值以上の降雨が生起したときに 少なくても速度規制が発令されている（雨量計の地点の 降水量が速度規制基準值以上）と考えられるためである. (c) 雨量計は, 直線の線路に等間隔で設置されているも のと仮定する (図-3) .

雨量計の設置間隔は, 表-1 に示寸安全性を曝露率と超 過関数, 安定性をダウンタイムで評価することにした.

これらは，図-4に示す解析フローにしたがって，2地点 のうちの 1 地点以上で $30 \mathrm{~mm}$ 以上の 1 時間降水量が観測 された場合の 2 地点の 1 時間降水量の降水量比および同 時生起率加求めた。

\section{1 時間降水量の空間分布}

\section{(1) 既往の研究}

\section{a) 1 時間降水量の降水量比}

鈴木ほか ${ }^{0}$ は，図-1 に示した関東平野の 347 地点て観 測された 1991 年から 2007 年の暖候期における正時の 1 時間降水量を用いて, 2 地点の 1 時間降水量の降水量比 と 2 地点間の距離との関係を解析した. 図-5には, 2 地 

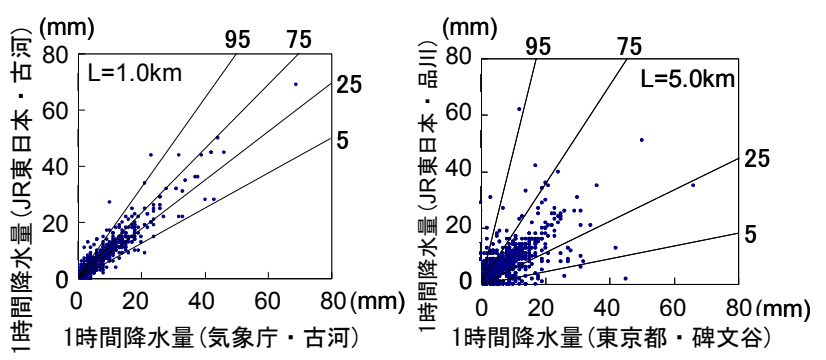

図-5 2 地点間の距離が $1 \mathrm{~km}$ および $5 \mathrm{~km}$ の場合の 1 時間降水量 の関係. 実線は横軸の地点に対する縦軸の地点の降水量 比に関する $5,25,75,95$ パーセンタイル值に対応する傾き を表す直線.

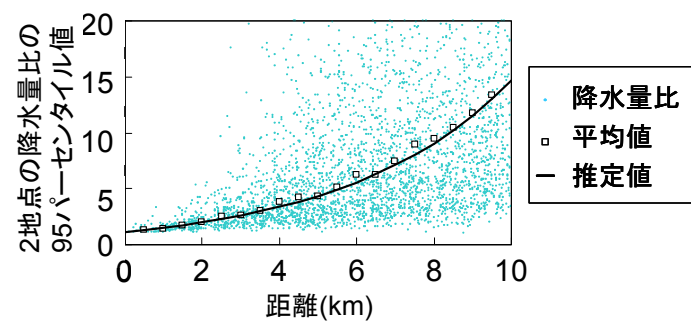

図-6 2 地点の 1 時間降水量の降水量比に関する 95 パーセンタ イル值と 2 地点間の距離との関係.

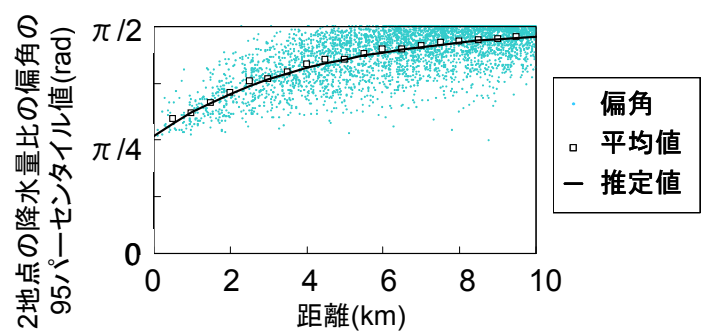

図-7 2 地点の 1 時間降水量の偏角に関する 95 パーセンタイル 值と 2 地点間の距離との関係.

点間の距離が $1 \mathrm{~km}$ と $5 \mathrm{~km}$ の雨量計の組合せについて, 正時の 1 時間降水量の関係を例示した. 図中の実線は, 2 地点のうちの 1 地点以上で $30 \mathrm{~mm}$ 以上の 1 時間降水量が 観測された場合について，横軸の地点に対する縦軸の地 点の降水量比に関する $5,25,75,95$ パーセンタイル值に 対応する傾きを表す直線である. なお，この 5,25 パーセ ンタイル值は縦軸の地点に対する横軸の地点の降水量比 の 95, 75 パーセンタイル值に相当する. 図-6には, 全て の雨量計の組合せについて，2 地点の 1 時間降水量の降 水量比に関する 95 パーセンタイル值と 2 地点間の距離と の関係を示した．また，図には示すことができないが 2 地点の降水量比に関する 95 パーセンタイル值は $2 \mathrm{~km}$ を 超えると無限大になる組合せが現れる. そこで, 図-7に は2地点の1時間降水量の関係を有限の值で表すために, これらの関係を極座標の偏角 (2 地点の降水量を $R a, R b$ としたときの $\theta=\arctan (R a / R b))$ で示した. これによって, 2 地点の 1 時間降水量と 2 地点間の距離との平均的な関 係を求めることができる. 図-7 の口は, ある距離士 $0.5 \mathrm{~km}$ の $1 \mathrm{~km}$ の範囲に含まれる組合せについて，2 地点の 1 時 間降水量の偏角に関する 95 パーセンタイル值の平均值

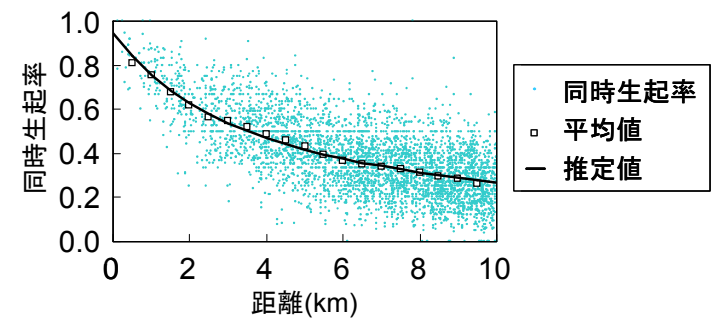

図-8 1 時間降水量の同時生起率と 2 地点間の距離との関係.

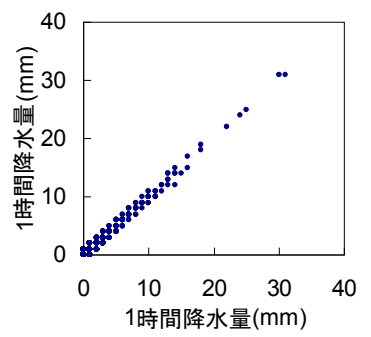

図-9 5m 離れた 2 地点の 1 時間降水量の関係

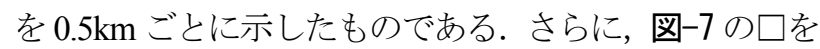
直角座標に変換すると， 2 地点の 1 時間降水量の降水量 比に関する 95 パーセンタイル值の平均值を求めること ができ，それを図-6にロで示した。

b） 1 時間降水量の同時生起率

鈴木・高橋 ${ }^{7}$ は，関東平野を対象（図-1）に，J R 東日 本と気象庁の雨量計で観測された 1991 年から 2005 年の 暖候期における正時の 1 時間降水量を用いて，1 時間降 水量の同時生起率と 2 地点間の距離との関係を解析した. 同時生起率 ${ }^{8)}$ は，ある地点の降水量があるしきい值以上 の場合に，もう一方の地点の降水量が同時にそのしきい 值以上になった割合である。図-8 は，しきい值を $30 \mathrm{~mm}$ とした場合の 1 時間降水量の同時生起率と 2 地点間の距 離との関係で，鈴木ほか 6)と同じ降水量データを用いて 再計算したものである.また，図中の $\square$ は図-7 と同様に 同時生起率の平均值を $0.5 \mathrm{~km}$ ごとに示したものである.

(2) 降水量の空間分布の数式化

a）同一地点とみなせる 2 地点の降水量の差異

仙台管区気象台調査課 ${ }^{13)}$ は，ほぼ同一地点とみなされ る一辺 $15 \mathrm{~m}$ の正三角形内の雨量計で観測されるひと雨 降水量に土6\%の差異があるとしている．そこで，2 地点 の 1 時間降水量の降水量比および同時生起率と 2 地点間 の距離との関係の数式化にあたって，2 地点間の距離が $0 \mathrm{~km}$ の場合の条件を把握するために, 2 基の雨量計を $5 \mathrm{~m}$ 間隔で設置して降水量の観測を 2 年間実施した. 図-9 は, 2 基の雨量計の正時における 1 時間降水量の関係である. ここでは， 2 地点のうちの 1 地点以上で $10 \mathrm{~mm}$ 以上の 1 時間降水量が観測された場合について，2 地点の 1 時間 降水量の降水量比に関する 95 パーセンタイル值を求め ると 1.10 と 1.11 であった。また，1 時間降水量の同時生 起率は 0.94 と 0.97 であった。このように，2 地点間の距 離が $0 \mathrm{~km}$ の場合に，これらは 1 になるはずであるが，観 測誤差などに起因して1にならないと考えられる. 


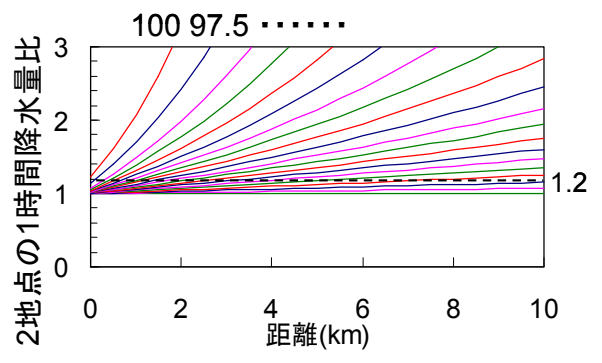

図-10 2 地点の 1 時間降水量の降水量比と 2 地点間の距離と の関係で, 50 から 100 パーセンタイル值までの 2.5 パ 一センタイル值ごとの関係.

\section{b） 1 時間降水量の降水量比の数式化}

2 地点の 1 時間降水量の降水量比に関寸るパーセンタ イル值と 2 地点間の距離との関係の数式化を行った. 初 めに 2 地点の 1 時間降水量の偏角に関する $p$ パーセンタ イル值 $r(p, x)$ と 2 地点間の距離 $x$ との関係式を求めた. 2 地点の 1 時間降水量の偏角に関する $p$ パーセンタイル值 と 2 地点間の距離との関係は, $p$ パーセンタイル值ごと に定まる $a(p), b(p)$ 係数とする指数型（式(1)）と分数型 (式(2)）の 2 種類の関係式を考えた. なお， $b(p)$ は 2 地 点間の距離が $0 \mathrm{~km}$ の場合における $\pi / 4$ (降水量比が 1 ) からの誤差を表す係数である.

$$
\begin{gathered}
r(p, x)=\frac{\pi}{2}-\frac{\pi}{4}(1-b(p)) \exp (-a(p) \times x) \\
r(p, x)=\frac{\pi}{2}-\frac{\pi / 4-b(p)}{1+a(p) \times x}
\end{gathered}
$$

式(1), (2)の係数 $a(p), b(p)$ は，図-2 のように雨量計の組 合せ数が 2 地点間の距離の増加とともに多くなることか ら, 各 $1 \mathrm{~km}$ 区間の組合せの寄与度が同じになるように, 各 $1 \mathrm{~km}$ 区間の組合せ数に応じて重み付けを行った上で, 最小二乗法を用いて推定した。 その結果，式(1)は式(2) に比べて 2 地点の 1 時間降水量の偏角に関寸る $p$ パーセ ンタイル值との誤差が小さいことから，2 地点の 1 時間 降水量の偏角に関寸る $p$ パーセンタイル值と 2 地点間の 距離との関係式には式(1)を採用することにした. 図-7 の実線は式(1)から算出される 2 地点の 1 時間降水量の偏 角に関する 95 パーセンタイル值を示したもので, $1 \mathrm{~km}$ 範囲ごとの平均值と良く一致する.これから， 2 地点の 1 時間降水量の降水量比に関する $p$ パーセンタイル值 $R(p, x)$ と 2 地点間の距離 $x$ との関係は, 式(1)を直角座標 に変換した下記の関係式で表すことができる.

$$
R(p, x)=\tan (r(p, x))
$$

図-6には, 式(3)から算出される 2 地点の 1 時間降水量 の降水量比に関する 95 パーセンタイル值と 2 地点間の距 離との関係を実線で示した.また, 図-10には 50 から 100 パーセンタイル值までの 2.5 パーセンタイル值ごとに 2 地点の 1 時間降水量の降水量比に関するパーセンタイル 值と 2 地点間の距離との関係を示した.

\section{c） 1 時間降水量の同時生起率の数式化}

1 時間降水量の同時生起率 $P(x)$ と 2 地点間の距離 $x$ と の関係は, 式(1), (2)と同様な指数型と分数型の 2 種類の

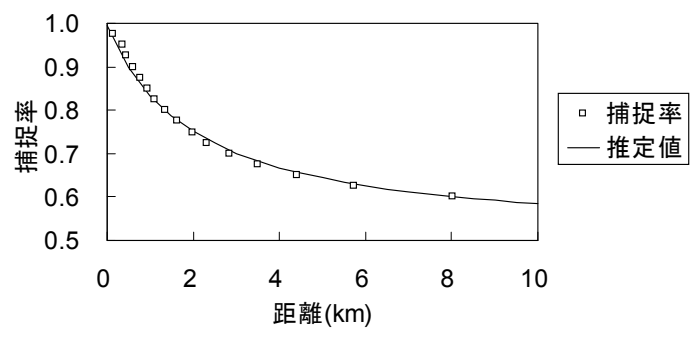

図-11 捕捉率と 2 地点間の距離との関係.

関係式を考えて，最小二乗法を用いて係数 $a, b$ を推定し た. その結果，分数型は指数型に比べて 1 時間降水量の 同時生起率との誤差が小さいことから，これらの間の関 係式には下記に示寸分数型を採用寸ることにした.

$$
P(x)=(1-b) /(1+a \times x)
$$

図-8 の実線は, 式(4)から算出される 1 時間降水量の同 時生起率を示したもので, $1 \mathrm{~km}$ 範囲ごとの平均值である ロと良く一致する.

\section{4 雨量計の設置間隔の評価}

\section{（1）曝露率}

曝露率は, 雨量計の地点と雨量計からある距離離れた 地点までの区間において，1 時間降水量の降水量比が 1.2 以上の降雨に曝される確率とする（表-1）。これは，雨 量計の地点の降水量が速度規制基準值に達していないと きに，雨量計の受け持ち範囲の半径（図-3 の $x$ ）にあた る区間のどこかで降水量が運転中止基準值以上である確 率と考えることにする.

曝露率を求めるにあたって, 初めに捕捉率を求めた. 捕捉率は, 雨量計の地点と雨量計からある距離離孔た地 点における 1 時間降水量の降水量比が 1.2 以下になる確 率とする. 捕捉率は, 式(3)の左辺 $R(p, x)$ を 1.2 として $x$ について解くことで求めることができ, 図-10 において 2 地点の 1 時間降水量の降水量比 $R(p, x)$ が 1.2 になる 2 地 点間の距離 $x$ として求めることができる. このようにし て求めた捕捉率が図-11 の $\square$ である. 捕捉率 $C(x)$ と 2 地 点間の距離 $x$ との関係は, 式(1), (2) と同様な指数型と分 数型の 2 種類の関係式を考えて, 最小二乗法を用いて係 数 $a, b$ を推定した. その結果, 分数型は指数型に比べて 捕捉率との誤差が小さいことから，これらの間の関係式 には次式に示す分数型を採用することにした.

$$
C(x)=0.5+(0.5-b) /(1+a \times x)
$$

図-11 の実線は, 式(5)から算出される捕捉率と 2 地点 間の距離との関係である.

雨量計の地点と雨量計からある距離離れた地点にお ける 1 時間降水量の降水量比が 1.2 以上になる確率は, 捕捉率の余事象 $(=1-C(x))$ になる. ここで, 距離 $x$ を 雨量計の受け持ち範囲の半径とすると, 曝露率 $E(x)$ はこ の区間における 1 時間降水量の降水量比が 1.2 以上にな る確率の平均值として, 次式で表すことができる.

$$
E(x)=\int(1-C(x)) d x / x
$$

図-12 は, 式(6)加算出される曝露率と雨量計の受け 


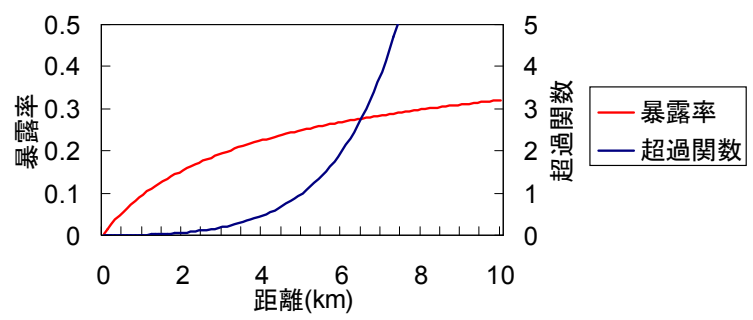

図-12 曝露率および超過関数と雨量計の受け持ち範囲の半径 (2 地点間の距離) との関係. 超過関数は雨量計の受け 持ち範囲の半径を $5 \mathrm{~km}$ で規格化.

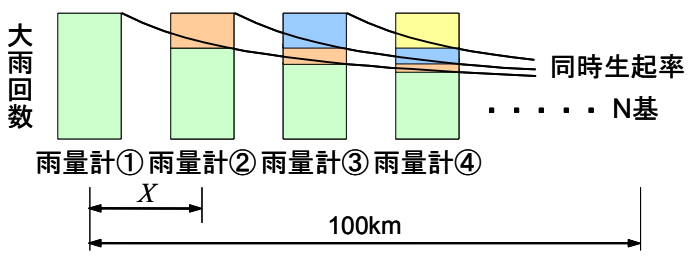

図-13 1 時間降水量の同時生起率と大雨回数の関係

持ち範囲の半径（2 地点間の距離）の関係で，曝露率は 収束型の増加関数である.

\section{（2）超過関数}

超過関数は, 雨量計の地点と雨量計からある距離離孔 た地点までの区間において，1 時間降水量の降水量比が 1.2 を超過した量を 2 乗和した平均值とする（表-1）。こ れは, 雨量計の地点の降水量が速度規制基準值に達して いないときに, 雨量計の受け持ち範囲の半径 (図-3 の $x$ ) にあたる区間において，降水量が運転中止基準值を超過 した量を評価する指標と考えることにする． 2 乗和する のは，降水量が運転中止基準值を超えても実際に降雨災 害が発生するのは稀であることから，僅かな超過であれ ば大目にみて，大きな超過に対しては厳しく評価するた めである. 雨量計から距離 $x$ の地点における 1 時間降水 量の降水量比が 1.2 を超過した量の 2 乗和 $l(x)$ は, 2.5 パ 一センタイル值ごとの 1 時間降水量の降水量比の $p$ パー センタイル值 $R(p, x)$ を用いて次式で示すことにした.

$$
\begin{array}{r}
l(x)=\sum(((R(p, x)-R(p-2.5, x)) / 2 \\
\left.-1.2)^{2} \times 0.025\right)
\end{array}
$$

ただし, $(R(p, x)-R(p-2.5, x)) / 2>1.2$ の場合のみ計算す ることとする. ここでは，距離 $x$ を雨量計の受け持ち範 囲の半径とすると, 超過関数 $L(x)$ はこの区間における 1 時間降水量の降水量比が 1.2 を超過した量の 2 乗和 $l(x)$ の平均值として次式で表すことができる.

$$
L(x)=\int l(x) d x / x
$$

図-12 は，式(8)から算出される超過関数と雨量計の受 け持ち範囲の半径 (2 地点間の距離) との関係で，雨量 計の受け持ち範囲の半径を $5 \mathrm{~km}$ で規格化して示した. こ れから, 超過関数は発散型の増加関数である.

\section{(3) ダウンタイム}

ダウンタイムは，運転中止基準值を 1 時間降水量が $30 \mathrm{~mm}$ とした場合の運転中止時間とする（表-1）。ダウ ンタイムを求めるにあたって, 初めに大雨回数を求めた. 鉄道は，路線ごとの運行になることから，一つの雨量計

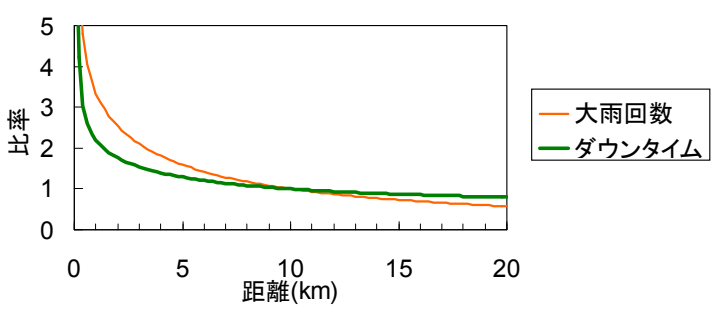

図-14 大雨回数およびダウンタイムと雨量計の設置間隔との 関係. 雨量計の設置間隔が $10 \mathrm{~km}$ の場合で規格化.

で運転中止になると全線で運行できなくなることが多い. そのため，ある路線における運転中止回数はある路線で 観測される大雨の回数の合計（大雨回数）になる. 大雨 の出現率が一様と仮定すると, 雨量計が等間隔 $(X$ : 雨 量計の設置間隔 $=2 x$ ）で設置されている場合には，ある 雨量計（図-13 の雨量計(1) で観測される大雨のうち隣 りの雨量計（図-13 の雨量計(2)）でも大雨として観測さ れるのは 1 時間降水量の同時生起率 $S(X)$ に相当する回数 である.よって, 雨量計(2)では同時生起率の余事象 $(=1-S(X))$ に相当する回数が雨量計(1)で観測されなか った大雨として新らたに観測されることになる.さらに, 隣り以降の雨量計についても同様である. これから，路 線延長 $L$ に雨量計が等間隔 $X$ で設置されている場合に観 測される大雨回数 $n(X)$ は, 次式で表すことができる.

$$
n(X)=1+(L / X-1)(1-S(X))
$$

図-14 は，路線延長 $L$ を $100 \mathrm{~km}$ とした場合の大雨回数 と雨量計の設置間隔との関係で，大雨回数は雨量計の設 置間隔が $10 \mathrm{~km}$ の場合で規格化して示した.

運転中止は，降水量が運転中止基準值に達した場合に 発令され，運転中止基準值を下回るとともに，運転規制 区間の線路巡回で線路に異常がないことが確認された場 合に解除になる．これから，運転中止時間は降水量が運 転中止基準值を超えている時間と線路巡回に要寸る時間 の合計になる.これから，1つの運転規制区間 $(X:$ 雨量 計の受け持ち範囲の直径) における運転中止の平均時間 $d(X)$ は, 1 時間降水量が $30 \mathrm{~mm}$ 以上の平均継続時間を $t$, 降水量が運転中止基準值を下回ってから線路巡回に出発 するまでに要する準備時間を $s$, 線路巡回の移動速度を $v$ とすると次式となる.

$$
d(X)=t+s+X / v
$$

線路巡回には雨量計の設置間隔に関わらず運転規制 区間ごとに 1 パーティーを充当できる，つまり同時に線 路巡回を実施できると仮定すると, ダウンタイム $D(x)$ は 大雨回数 $n(X)$ と運転中止の平均時間 $d(X)$ の積になり, 次 式で表すことができる.

$$
D(X)=n(X) \times d(X)
$$

1 時間降水量が $30 \mathrm{~mm}$ 以上の平均継続時間 $t$ は, JR 東 日本の雨量計 110 箇所の 5 分ごとの降水量データを用い て算出寸ると 45 分であった. また, 準備時間 $s$ および線 路巡回の移動速度 $v$ は, JR 東日本千葉支社管内における 実績から 46 分および $178 \mathrm{~m} /$ 分とした.

図-14 は，路線延長 $L$ を $100 \mathrm{~km}$ とした場合のダウンタ 


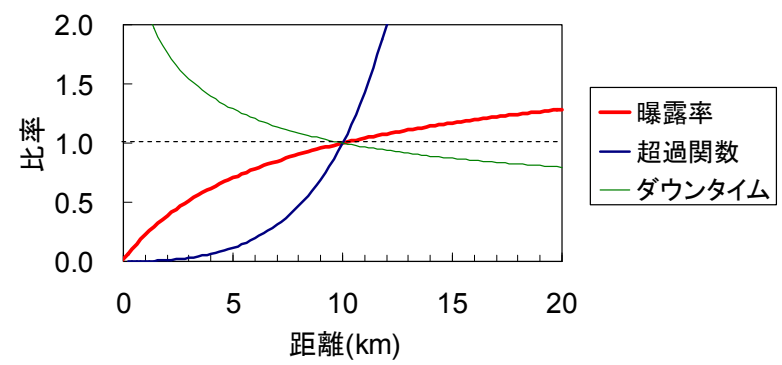

図-15 曝露率, 超過関数，ダウンタイムと雨量計の設置間隔 の関係. 雨量計の設置間隔が $10 \mathrm{~km}$ の場合で規格化.

イムと雨量計の設置間隔との関係で，ダウンタイムは雨 量計の設置間隔を $10 \mathrm{~km}$ で規格化して示した. これから, ダウンタイムは収束型の減少関数である. なお，運転中 止区間の線路巡回を同時にできるとする仮定は，雨量計 の設置間隔が極端に小さい場合に成り立たないことから， 図-14 に示したダウンタイムは雨量計の設置間隔が極端 に小さい場合には最小値を示していることになる。

\section{5 考察}

雨量計の設置間隔に関寸る考察では，雨量計の受け持 ち範囲の半径 $x$ と雨量計の設置間隔 $X$ が $X=2 x$ の関係に ある (図-3) ことから, 曝露率, 超過関数, およびダウ ンタイムと雨量計の設置間隔で議論寸る．図-15 は，曝 露率 $E(X)$, 超過関数 $L(X)$, およびダウンタイム $D(X)$ と雨 量計の設置間隔 $X$ との関係で, 雨量計の設置間隔が $10 \mathrm{~km}$ の場合で規格化して示した.

図-15によると，超過関数は $5 \mathrm{~km}$ 程度以下では増加率 が小さいが，5km 程度以上では増加率が大きくなる発散 型の増加関数である. そのため, 超過関数の観点からみ た安全性は, 雨量計の設置間隔を $5 \mathrm{~km}$ 程度以下にすると, $10 \mathrm{~km}$ の場合に比べて著しく向上寸ると考えられる. 雨 量計の設置間隔が $5 \mathrm{~km}$ の場合には，10km の場合に比べ て超過関数は 88\%減少する. 一方, 曝露率およびダウン タイムは $5 \mathrm{~km}$ 程度以下では増減率が大きいが, $5 \mathrm{~km}$ 程度 以上では増減率が小さくなる収束型の増加関数および咸 少関数である. 曝露率の減少率とダウンタイムの増加率 を比べると, 雨量計の設置間隔が $5 \mathrm{~km}$ 程度を境に, それ 以下では後者，それ以上では前者が大きくなる. 雨量計 の設置間隔を $10 \mathrm{~km}$ から $5 \mathrm{~km}$ にした場合には，曝露率の 減少率とダウンタイムの増加率はそれぞれ $29 \%$ である. よって, 雨量計の設置間隔を $10 \mathrm{~km}$ から $5 \mathrm{~km}$ にすると, 曝露率とダウンタイムの関係からみた安全性の向上と安 定性の低下は同等である。

したがって，雨量計の設置間隔を鉄道の多くが標準と している $10 \mathrm{~km}$ から $5 \mathrm{~km}$ ，すなわち雨量計の受け持ち範 囲の半径を $5 \mathrm{~km}$ から $2.5 \mathrm{~km}$ に半減すると, 安全性の評価 基淮とした曝露率の減少率と安定性の評価基準としたダ ウンタイムの増加率がほぼ同等であるとともに, 安全性 の基準とした超過関数を大幅に減少させることができる つまり, 曝露率とダウンタイムの関係からみた安全性の
向上と安定性の低下は同等であるが, 超過関数の観点か らみると安全性が著しく向上寸る.これから, 雨量指標 に 1 時間降水量を用いた場合の雨量計の設置間隔は $5 \mathrm{~km}$ が一つの目標であると考えられる.

\section{6 おわりに}

本研究では, 鈴木ほかのや鈴木・高橋7゙によって行われ た2地点の1時間降水量の降水量比および同時生起率と2 地点間の距離との関係に関する研究成果を利用して, 鉄 道における雨量計の設置間隔を評価する方法について考 察した. その結果, 鉄道における雨量計のより適切な設 置間隔の設定方法を提案するとともに，降雨強度の雨量 指標として用いられることの多い1時間降水量を雨量指 標に用いた場合の雨量計の設置間隔は $5 \mathrm{~km}$ が一つの目標 であることを導いた。 また，今後は長期雨量（24時間降 水量など）やJR東日本の列車運転規制に用いられている 実効雨量について, 同様の解析を行うことで, 研究成果 を実務に反映させて行きたいと考えている.

謝辞 : 本研究では, 気象庁, 国土交通省, 東京都, およ び JR 東日本の降水量データを利用しました．それぞれ の機関において観測とデータの保存・整理に従事された 方々に深く感謝申し上げます。

\section{参考文献}

1) 島村 誠: 降雨・河川増水に対寸る運転規制方法等の改正, 日本鉄道施設協会誌, Vol.35, pp.437-440, 1989.

2) 岩井美津雄: 在来線防災情報収集システムの開発・導入, 日 本鉄道施設協会誌, Vol.42, pp.136-138, 1996.

3) 村上隆博, 菊井稔宏, 嶋 大尚, 清水基成: 雨量計の有効範 囲に関する一考察，砂防学会誌，Vol.61，pp.16-22，2008.

4) 井良沢道也, 田口隆男: 降雨特性を考慮したテレメー夕配置 計画の検討, 新砂防, Vol.49, pp.22-27, 1996.

5）建設省土木研究所砂防部砂防研究室: 土石流の警戒・避難基 準雨量の設定に関寸る研究, 土木研究所資料, No.2215, 79pp, 1985.

6) 鈴木博人, 高橋日出男 : 関東平野における大雨の空間スケー ルー鉄道と気象庁の降水量データを用いた統計解析一，自然 災害科学, Vol.27, pp.161-173, 2008.

7) 鈴木博人, 中北英一, 高橋日出男: 雨量計の観測值を用いた 降水量の空間代表性の解析, 水工学論文集, Vol.53, pp.391-396, 2009.

8) 葛葉泰久, 友杉邦雄, 岸井徳雄: 降水量の空間相関構造, 水 工学論文集, Vol.46, pp.127-132, 2002.

9) 加藤 光：防災情報システムの導入, Japan Railway Engineers' Association, Vol.32, pp.18853-18856, 1989.

10）国土交通省：水文水質データベース, http://www1. river.go.jp, 2010 年 9 月 30 日.

11) 東京都: 東京都水防災総合情報システム, http://www.kasensuibo.metro.tokyo.jp/im/tsim0101g.html，2010 年 9 月 30 日.

12) 村石 尚, 杉山友康, 香川清治: 実効雨量による災害予測 法の検討，鉄道総研報告，Vol.9，pp.7-12，1995.

13）仙台管区気象台調査課: 降雨特別調査観測について, 研究 時報, No.26, pp.16-17, 1974.

(2010. 9.30 受付) 